\title{
Safety in ensuring the quality of production - the role and tasks of standards requirements
}

\author{
Adam Górny* \\ Poznan University of Technology, Faculty of Management Engineering, Poznan, Poland
}

\begin{abstract}
During the performance of manufacturing tasks, safety - which is a primary responsibility of employers - has a major impact on production quality. To achieve such safety, employers must ensure working conditions that reflect worker needs and meet technical and organizational requirements. Safety requirements are designed to foster threat- and strainfree work in the workplace. By striving to comply with such requirements, organizations improve the conditions in which their production is performed. In their effort to incorporate essential principles into their systems, employers can benefit from applying the ISO 45001 standard, which defines the systemic requirements that must be embraced in their business in the same manner as the requirements adopted in any other field of activity, such as production quality. The article refers to standards derived from ISO 45001 that facilitate manufacturing improvements. It outlines the impact of systemic enhancements on workers' ability to perform work safely.
\end{abstract}

\section{Introduction}

Measures aimed at ensuring safe working conditions are commonly adopted to make certain that production proceeds in conditions that are compatible with the needs of persons who remain on the production floor [1-3]. Once working conditions meet the expectations of such persons, direct and indirect benefits are achieved, among them greater efficiency, lower absenteeism and reduced strenuousness. On the other hand, unsafe working conditions disturb production processes [1,4].

Risk factors, unsafe working conditions and work-related injuries reduce the efficiency of operations and impair the functioning of processes. Occupational accidents, diseases and incidents negatively affect performance, as revealed by relevant indicators $[5,6]$. Such events impact on workers' ability to perform production tasks efficiently and effectively and the company's capacity to make improvements defined as the ability to meet the expectations of the concerned parties [7].

Organizations are responsible for identifying and either eliminating or mitigating threat impacts. To that end, they should select areas for monitoring so as to ensure that, among others, their effect on manufacturing is continuous and effective [1]. To make certain that the selected measures are indeed effective, it is essential to embrace occupational safety

\footnotetext{
*Corresponding author: adam.gorny@put.poznan.pl
} 
standards. One such standard is ISO 45001, which defines principles for systemic occupational health and safety management. The article outlines some of the key effects and applications of the above standard for shaping the manufacturing environment.

\section{Standards requirements in the systemic management of production safety}

The aim of managing an organization's activities is to achieve specific benefits. This principle can also be applied to production management.

A management system should include areas of importance for securing the effective implementation of specific activities. These include [8, 9-11]: an organization structure that facilitates task implementation, people taking ownership of the decisions they make and the tasks they perform, and proper planning of actions, goals and resources. It is therefore critical in the technical, organizational and human aspects to define rules and procedures for the normal course of work as well as emergencies, keep a record of any measures and decisions taken, ensure efficient and effective information flows along vertical and horizontal lines in the organization's management structure, and ensure proper purchasing and subcontracting [12]. Such activities are identified in the most common management standards $[13,14]$. Equally important is the extension of the requirements to human and cultural aspects of the organization's functioning as well as its relations with any concerned parties [7, 15].

An organization whose management is process-centered should place a great deal of emphasis on any processes that enable it to meet customer needs and expectations. Of essential importance in this approach are links across processes. The organizations that take proper account of such links will benefit from optimal interactions between processes, fulfilling needs of the concerned parties and gaining the ability to bring their management to the desired level of maturity [8]. To improve the environment in which production is performed, organizations should ensure they are able to either eliminate or reduce the impacts of the causes of irregularities on workers. To that end, they should focus on the threats and nuisances that impair their ability to carry out production tasks $[16,17]$.

For a number of years now, safety requirements have featured prominently in the overall standards landscape. Safety standards are defined as guidelines for managing the work environment and ensuring that production proceeds efficiently and effectively [8]. It is equally common to incorporate the principles of systemic safety management into TQM requirements, often in the form of Total Safety Management [3, 18-20]. TQM allows organizations to optimize the way problems are solved with proper account taken of improvements in efficiency and stakeholder satisfaction, which in turn create an environment that fosters better work performance.

To create a friendly working environment, organizations commonly employ standards governing the management of working condition and work safety, risk assessment and management, and threat prevention and mitigation. They accomplish these aims by implementing corrective and preventive measures. At the heart of work safety management lies risk assessment. Such assessment should apply to both worker performance and their ability to carry out tasks.

To help meet the above goals, a new occupational health and safety management standard named ISO 45001 has been developed. Under its premises, improvements relying on the application of ISO 45001 are to help standardize and improve systemic activities, primarily in organizations that have previously implemented such activities in other areas of management $[3,7]$. Improvement measures can be performed in the same manner as those carried out in other areas of an organization's operations. 


\section{Occupational safety management standards based on ISO 45001 requirements}

\subsection{Objectives and applications of ISO 45001 standard}

ISO 45001 should be seen as support in integrating an operational control system [17]. The operational parameters of processes, including those of the environment in which the processes are performed, require adequate monitoring [1,13]. Such monitoring is crucial for averting the risks that arise in the course of process implementation affecting the achievement of intended and desired effects.

The structure of the standard mimics that of the management guidelines adopted in ISO 14001 (EMS) and ISO 9001 (QMS). Its approach to systemic management relies on the continual PDCA improvement loop, in which a special role is ascribed to leadership and the management's responsibility for the measures taken [21]. The standard is also intended to enable the organization to deliver on its commitments [22]. Compliance with systemic rules requires a broad view on any issues. Risk assessment and operational control over activities alone are therefore considered to be insufficient [12].

An organization that establishes an ISO 45001 compliant management system should be able to:

- Adopt effective work safety management principles tailored to the specific nature of the organization's operations, in keeping with the PDCA model, consistently with the improvement principles applied in other areas of the company's management,

- Define any processes that play a role in reducing work strain, taking into account their context and operating risks as well as any applicable legal requirements,

- Identify any threats and assess any risks that compromise the organization's ability to perform tasks,

- Raise worker awareness of hazards and improve the organization's ability to describe hazards based on risk assessment,

- Assess the effectiveness of the measures taken to improve occupational safety, prevent injuries and protect people's health,

- Develop an occupational safety and health protection culture across the organization,

- Promote health education, with training recognized as essential for continuous improvement and for the effectiveness of improvement measures,

- Provide employees with opportunities to actively contribute to the promotion of safety at work.

The outcomes of the measures taken should be viewed as worker health improvements achieved by way of systemic occupational health and safety management $[3,14]$. To enjoy such benefits, organizations need to ensure that both their workers and management engage in promoting occupational safety $[7,19,20]$.

\subsection{ISO 45001 requirements}

The ISO 45001 standard offers manufacturing safety guidelines that recognize the special role played by human operators. Once implemented, the standard can be said to help enhance processes and specifically improve:

- The effects of activities and how they interrelate with each other,

- Organizational structures and the performance of tasks within organizations,

- Human and cultural aspects of organizations' functioning,

- Infrastructure, the work environment and technologies,

- Relations and interdependencies with all concerned parties. 
At its core, systemic management focuses on $[7,9,16,17,21]$ :

- The context of an organization's functioning

Requirements applicable to operations should be associated with management objectives highlighting the organization's duty to ensure occupational safety and comply with the laws that the organization has committed to observe. To that aim, the environment in which the company is operating needs to be recognized in its management system. Hence, an analysis of the organization's environmental impacts will be required [4].

- Assessment of the effects of measures

To comply with requirements, organizations need to rely on indicators that describe their activities. The standard relies on a dual assessment of the results, focused on efficiency and system performance. In the realm of occupational safety, this is achieved by preventing worker injuries and any adverse health impacts.

- Scope of management system

The system must encompass an occupational safety policy. Its scope extends to any company activities, products and services that in any way affect occupational safety. Both existing and potential threats should be taken into account. Such factors need to be assessed and monitored. The verification should include any outsourced work and any external processes that affect the organization's functioning.

- Leadership

The management is obliged to strive to improve the effectiveness of the work safety management system and support any people responsible for such effectiveness. It should therefore fully integrate system requirements with ongoing production processes. Specifically, organizations should include management effectiveness issues in their strategic planning.

- Concerned parties

Organizations have a duty to name the parties that influence the functioning of their management system and define the rules that such parties should follow.

- Risk assessment and management

Risk assessment should be viewed as an instrument for verifying the conditions in which humans operate in the work environment. In addition to its traditional safety applications, risk assessment provides a way to gauge the impact of uncertainty on the effects of an organization's operations and the ability to achieve intended results that are consistent with the level of management maturity achieved by the organization.

\section{Production safety requirements}

ISO 45001 relates to managing occupational safety. The improvements sought through compliance with systemic requirements allow companies to take effective measures to meet the needs of all stakeholders, including those in their external environment. This contributes to making the measures more effective, mainly as a result of the skills acquired and the ability to anticipate changes, prepare the organization for their occurrence and ensure it responds appropriately. This allows organizations to maintain growth and improve their capacity to carry out production tasks.

Table 1 presents selected impacts of the normative requirements specified in ISO 45001 on the ability to safely implement production processes. Such safety is achieved chiefly by striving to improve the ability to perform work and augment the environment in which production tasks are performed. 
Table 1. The potential for safe performance of work achieved through compliance with ISO 45001

\begin{tabular}{|c|c|}
\hline $\begin{array}{c}\text { Area } \\
\text { of ISO } 45001 \\
\text { requirements }\end{array}$ & Measures taken to ensure safe performance of work \\
\hline $\begin{array}{l}\text { Context of } \\
\text { organization's } \\
\text { functioning }\end{array}$ & $\begin{array}{l}\text { - Measures that enable organizations to understand the need and see the } \\
\text { potential for performing tasks that contribute to safety improvements, } \\
\text { - A better understanding of the need to strive to enhance occupational } \\
\text { safety management systems with a view to improving occupational } \\
\text { safety, } \\
\text { - Ensuring an effective identification of threats and opportunities for their } \\
\text { prevention, } \\
\text { - Clearly defining organizations' responsibility for identifying } \\
\text { occupational safety objectives, } \\
\text { - Extending supervision over the obligations and tasks that contribute to } \\
\text { occupational safety improvements, in keeping with applicable national } \\
\text { and international legislation. }\end{array}$ \\
\hline $\begin{array}{l}\text { Scope of OHS } \\
\text { management } \\
\text { system }\end{array}$ & $\begin{array}{l}\text { - Incorporating all actions, products and services whose performance and } \\
\text { provision affects worker safety, } \\
\text { - Ongoing oversight over all efforts made with proper account taken of } \\
\text { occupational safety issues, } \\
\text { - Oversight and monitoring of any outsourced work, } \\
\text { - Oversight and monitoring over internal processes that affect the } \\
\text { organization's operation, } \\
\text { - Assessment of identified impacts against acceptable reference values } \\
\text { adopted by the organization, } \\
\text { - Use of the findings of a review of the causes of errors and complaints as } \\
\text { well as of customer expectations and satisfaction to improve } \\
\text { occupational safety management system. }\end{array}$ \\
\hline Leadership & $\begin{array}{l}\text { - Ensuring full integration of business processes with systemic } \\
\text { requirements, } \\
\text { - Accounting - in the adopted approach - for the commitments and rules } \\
\text { derived from the principles of systemic occupational safety management, } \\
\text { - Demonstrating commitment to identify and take measures aimed at } \\
\text { increasing safety levels, } \\
\text { - Incorporating applicable laws and other obligations adopted by the } \\
\text { organization into regular practice. }\end{array}$ \\
\hline & $\begin{array}{l}\text { - Identifying all parties whose actions may affect the functioning of the } \\
\text { occupational safety management system, } \\
\text { - Using third party commitments to improve system functioning and } \\
\text { occupational safety, } \\
\text { - Identifying (and establishing the priority of) the requirements that need } \\
\text { to be observed by the concerned parties to help improve occupational } \\
\text { safety, } \\
\text { - Ongoing checks of the compliance of all concerned parties with } \\
\text { applicable laws adopted and recognized as significant for ensuring the } \\
\text { proper operation of the organization, } \\
\text { - Prioritizing improvements on the basis of input data received from the } \\
\text { concerned parties. }\end{array}$ \\
\hline
\end{tabular}

The measures specified in Table 1 allow companies to benefit in many areas of their operation. These include $[3,12,14,21]$ :

- Increased ability to achieve compliance with new mandatory legal requirements,

- Reduced costs of accidents and strain caused by failures to comply with requirements,

- Reduced costs of production downtime and disruptions,

- Lower insurance premiums as a result of decreased accident rates, 
- Reduced absenteeism affecting the timeliness of task performance.

However, to mitigate strains on work safety, organizations commonly need to modify their management practices and principles [2].

\section{Conclusions}

The adoption of the international ISO 45001 standard may contribute to improvements in the way working conditions are managed with positive effects on the quality of production processes. Normative requirements are of great use in the implementation of improvement activities, as they are crucial for organizations' ability to perform production tasks. Success in achieving the intended effects depends vitally on ensuring the active engagement of companies' workers and representatives.

\section{References}

1. E. Bottani, L. Monica, G. Vignali, Safety Science, 47(2), 155-162 (2009)

2. T. Karkoszka, Procedia Manufacturing, 13, 1463-1469 (2017)

3. A. Górny, Management Systems in Production Engineering, 3(14), 106-111 (2014)

4. R.L. Granerud, R.S. Rocha, Safety Science, 49(7), 1030-1039 (2011)

5. B. Fernández-Muñiz, J.M. Montes-Peón, C.J. Vázquez-Ordás, Safety Science, 70, 295307 (2014)

6. A. Górny, MATEC Web of Conferences, 94, 04011 (2017)

7. A. Górny, Modern Management Review, XX(22), 73-88 (2015)

8. ISO 9001:2015, Quality management systems. Requirements, International Organization for Standardization (International Organization for Standardization, Geneva, 2015)

9. ISO 45001:2018, Occupational health and safety management systems. Requirements with guidance for use (International Organization for Standardization, Geneva, 2018)

10. A. Górny, Proceedings of International Conference on Innovative Technologies, The work environment in the structure of management system (Faculty of Engineering University of Rijeka, Rijeka, 2013)

11. J. Tabor, Polish Journal of Management Studies, 7, 188-200 (2013)

12. S. Nenonen, The Service Industries Journal, 33(1), 99-114 (2013)

13. E. Lafuente, J. Abad, Safety Science, 103, 12-22 (2018)

14. K. Frick, Safety Science, 49(7), 974-987 (2011)

15. P. Babović, Acta Medica Medianae, 48(4), 22-26 (2009)

16. ISO/CD 45001, Occupational health and safety management systems. Requirements with guidance for use (BSi, London, 2014)

17. ISO 45001, New International Standard for Occupational Health \& Safety Management Systems. http://www.bsigroup.com/en-GB/ohsas-18001-occupational-health-and-safety/ ISO-45001 (date of access: September, 15, 2017)

18. J. Álvarez-Santos, J.Á. Miguel-Dávila, L. Herrera, M. Nieto, Safety Science, 101, 135-143 (2018)

19. A. Górny, Communications in Computer and Information Science, 529, 136-142 (2015)

20. A. Górny, Occupational Safety and Hygiene, Work environment in quality assurance, (Portuguese Society of Occupational Safety and Hygiene, Guimarães, 2016)

21. A. Górny, MATEC Web of Conferences, 94 (2017)

22. Fernández-Muñiz, J.M. Montes-Peón, C.J. Vázquez-Ordás, J. of Loss Prevention in the Process Industries, 50(B), 403-415 (2017) 